\title{
PEOPLE OF THE BOOK DAN GAGASAN PLURALISME KEAGAMAAN DALAM ALQURAN
}

\author{
Asep Muhamad Iqbal \\ Fakultas Ilmu Sosial dan Ilmu Politik, Universitas Islam Negeri Sunan Gunung Djati Bandung, Indonesia \\ E-mail: am.iqbal@uinsgd.ac.id
}

\begin{abstract}
To a certain extent, globalization has provided religions with opportunities to play their roles more extensively and encounter each other more openly than before. In addition to its advantages, this has created a tendency of rigid and exclusive ways of religiosity among different religious believers when they encounter each other or with other cultures. For most believers, this is a way of claiming religious identities, which should be maintained and defended. This article deals with what Islam as a system of belief has contributed to religious pluralism. Using the thematic method of interpretation, it focuses on its analysis on Quranic verses of Ahl al-Kitab, a term that refers to People of the Book. The article argues that from the Quranic perspective, religious pluralism is valid and constitutes one of the main principles of Quranic teachings. Religions of People of the Book differ in terms of syir'ah and minhaj, but they at the same time share a substantial similarity in terms of din, which is seen in their shared doctrine of monotheism (tawhid). To this monotheism, Alquran calls other religions to find a common term. This inclusive religiosity plays as the basis of how Alquran responds to other religions: it acknowledges their validity as systems of belief and emphasizes the shared point as seen in its response to the opposition of People of the Book in the early Islam (Jews and Christians).
\end{abstract}

Keywords:

People of the Book, Alquran; ahl al-kitab; Jews; Christians; religious pluralism; globalisation.

\begin{abstract}
Abstrak
Pada batas tertentu, globalisasi telah menyediakan peluang-peluang bagi agama-agama untuk lebih muncul dan bertemu satu-sama lain. Di samping dampak positif, hal ini menimbulkan kecenderungan cara keberagamaan yang rigid, eksklusif dan akhirnya isolasi pemeluk suatu agama ketika dihadapkan dengan agama dan kultur lain yang dianggapnya asing dan destruktif. Bagi umumnya pemeluk agama, sikap seperti ini merupakan penegasan identitas keagamaan yang memang sudah semestinya dipertahankan. Artikel ini membahas apa kontribusi Islam sebagai sebuah sistem keagamaan bagi persoalan pluralitas keagamaan ini. Dengan menggunakan metode tafsir tematik, artikel ini memfokuskan analisisnya pada ayat-ayat People of the Book (Ahl al-Kitab). Artikel ini berargumen bahwa dalam perspektif Alquran, pluralisme keagamaan merupakan persoalan yang absah dan salah satu prinsip dasar Alquran. Meskipun berbeda dalam bentuk syir'ah dan minhaj, pada saat yang sama agamaagama People of the Book (Yahudi dan Nasrani) memiliki kesamaan substansial pada dimensi-dalamnya atau din dalam istilah Alquran, yang terletak pada ajaran monoteisme (tawhid). Kepada monoteisme inilah Alquran mengajak agama-kitab lainnya untuk mencari titik-temu. Cara keberagamaan yang inklusif ini mendasari sikap dan respon Alquran terhadap agama-agama lain: tidak menafikan validitasnya dan lebih menekankan pada titik kesamaan seperti yang diperlihatkan dalam merespon oposisi People of the Book (komunitas Yahudi dan Nasrani di Madinah).
\end{abstract}

Kata Kunci:

People of the Book, Alquran; ahl al-kitab; Yahudi; Kristen; pluralisme keagamaan; globalisasi.

DOI: $10.15575 /$ jw.v3i2.3582

Received: November 2018; Accepted: December 2018; Published: December 2018 


\section{A. PENDAHULUAN}

Dunia kini dengan kekuatan teknologi informasi dan transportasinya yang mempunyai jangkauan yang sangat luas telah berubah menjadi sebuah desa global (global village) yang tidak lagi mempermasalahkan sekat-sekat geografis, sosio-kultur atau tatanan politik tertentu. Kreasi desa global ini, pada kenyataannya, melahirkan masyarakat yang transparan satu sama lain. Ia telah menyebabkan munculnya masyarakat kosmopolit secara kultural sebagaimana dilukiskan Naisbitt dan Aburdene dalam Megatrends 2000, minum cappucino, makan sushi, berbusana United Color of Benetton, mendengarkan musik rock AS-Inggris dan mengemudikan Hyundai menuju McDonald. ${ }^{1}$

Dalam arus globalisasi, masyarakat menjadi saling mempengaruhi satu sama lain. Dalam tingkat intensitas tertentu, hal ini mengimplikasikan adanya homogenisasi dan suatu kekuatan budaya dan politik yang dominan. Suatu bangsa bisa jadi akan kehilangan identitas kulturalnya akibat serbuan kultur hegemonistik yang tidak bisa dihindarinya. Pada konteks ini, apa yang dinamakan oleh Naisbitt dan Aburdene sebagai countertrend akan muncul ke permukaan. Di hadapan homogenisasi sebuah kultur yang notabene berasal dari luar, suatu masyarakat atau suatu bangsa akan berusaha melestarikan identitasnya, apakah itu kultur, kebangsaan, bahasa, ras bahkan agama. $^{2}$ Pada kondisi seperti ini, countertrend tersebut bisa mewujud dalam bentuk nasionalisme kultural dan eksklusivisme.

Dalam hal agama, tema pokok artikel ini, kecenderungan ini akan menimbulkan cara keberagamaan yang rigid, eksklusif dan akhirnya isolasi pemeluk suatu agama ketika dihadapkan dengan agama dan kultur lain yang dianggapnya asing dan destruktif. Bagi umumnya pemeluk agama, sikap seperti ini merupakan penegasan identitas keagamaan

\footnotetext{
${ }^{1}$ John Naisbitt and Patricia Aburdene, Magatrends 2000 (Jakarta: Binarupa Aksara, 1990), 106.

${ }^{2}$ Naisbitt and Aburdene, Magatrends 2000, 131.
}

yang memang sudah semestinya dipertahankan.

Hal ini terjadi karena secara mendasar agama dipandang sebagai klaim kebenaran (truth claim) oleh para penganutnya. Pada kondisi masyarakat yang transparan, masyarakat penganut agama dihadapkan pada persoalan klaim kebenaran agama lain yang sudah pasti diyakini dengan sepenuh hati. Maka, keadaan ini memungkinkan peluang yang potensial bagi tumbuhnya konflik antaragama, friksi antar atau intramasyarakat, dan, meminjam istilah Huntington, ${ }^{3}$ "benturan peradaban". Inilah masalah yang bisa ditimbulkan oleh adanya pluralitas atau keanekaragaman agama (religious plurality).

Persoalan lebih serius yang bakal terjadi adalah alih-alih masyarakat global (yang juga sudah terkena efek-efek modernitas yang pada beberapa hal menyebabkan kehilangan orientasi hidup dan kekeringan spiritual) semakin menghayati keberagamaannya, malah semakin menjauhi agama karena dipandang sebagai sumber pertentangan dan tidak bisa memberikan apa-apa bagi problem manusia modern. Agama bisa jadi akan ditinggalkan pemeluknya. Naisbitt dan Aburdene mengemukakan data-data tentang merosotnya pemeluk agama-agama utama (organized religions) di Amerika Serikat akibat ditinggalkannya oleh pemeluknya yang lari ke spiritulitas tanpa agama atau pseudo religions (agama semu). ${ }^{4}$

Melihat permasalahan di atas, penting kiranya menengok Islam sebagai sebuah agama besar dunia dengan sebuah pertanyaan fundamental: Apa kontribusi Islam sebagai sebuah sistem keagamaan bagi persoalan pluralitas keagamaan ini? Untuk menjawab pertanyaan ini, artikel ini membahas perspektif Alquran sebagai kitab suci Islam tentang pluralitas keagamaan. Dengan menggunakan metode tafsir

3 Samuel Phillips Huntington, "Benturan Kebudayaan, Masa Depan Politik Dunia?," Ulumul Qur'an 4, no. 5 (1993).

${ }^{4}$ John Naisbitt and Patricia Aburdene, Magatrends 2000 (Jakarta: Binarupa Aksara, 1990). 
tematik ${ }^{5}$, artikel ini memfokuskan analisisnya pada ayat-ayat People of the Book (Ahl alKitab). Ia berargumen bahwa dalam perspektif Alquran, pluralisme keagamaan merupakan persoalan yang absah dan natural sebagai bagian dari kehendak Tuhan dan karena itu Alquran mengajak kepada cara keberagamaan yang inklusif ketika penganut suatu agama berhadapan dengan penganut agama-agama lain dengan cara tidak menafikan validitas suatu agama dan lebih menekankan pada titik kesamaan seperti yang diperlihatkan dalam merespon oposisi People of the Book (komunitas Yahudi dan Nasrani di Madinah).

Sebenarnya, telah cukup banyak sarjana dan peneliti yang mengkaji tentang People of the Book sebagai bangsa atau komunitas yang diyakini telah diberi oleh Tuhan kitab suci sebelum kedatangan Islam dengan Alquran sebagai kitab sucinya. Secara umum, karyakarya mereka ini dapat dibagi ke dalam tiga kategori. Pertama, karya-karya yang berupaya membahas isu-isu People of the Book dengan merujuk kepada Alquran sebagai sumber utamanya. ${ }^{6}$ Ini dimaksudkan untuk menggali perspektif Alquran mengenai bangsa atau komunitas penerima kitab suci tersebut. Kedua, karya-karya yang membahas People of the Book dengan rujukan utama kepada Hadis sebagai sumber ajaran Islam kedua setelah Alquran. ${ }^{7}$ Sejalan dengan kategori yang pertama, karya-karya kategori kedua ini

\footnotetext{
${ }^{5}$ Tentang tafsir tematik dan langkah-langkah operasional penggunaanya, Lihat, Issa J Boulatta, "Modern Qur'an Exegesis: A Study of Bint Ash-Shathi's Method," The Muslim World 64, no. 2 (1974): 104-105.

${ }^{6}$ Ishmael Albayrak, "The People of the Book in the Qur'an," Islamic Studies 47, no. 3 (2008): 301-325. Lihat juga Jarot Wahyudi, "Exegetical Analysis of The Ahl Al-Kitab Verses of the Qur'an," Islamic Studies 37, no. 4 (1998): 425-43. Lihat juga Naila Farah, "Konsep Ahl Al-Kitab Menurut Pemikiran Rasyid Ridha Dalam Tafsir Al-Manar," Rausyan Fikr 12, no. 2 (2016): 221249. Lihat juga Zulyadain, "Menimbang Kontorversi Pemaknaan Konsep Ahl Al-Kitāb Dalam Al-Qur'an," Ulumuna Jurnal Studi Keislaman Volume 16, no. 2 (November, 2012): 279-310. Lihat juga Syamsudin Nasution, "Makna Ahl Al-Kitab Dalam Al-Qur'an (Suatu Kajian Tematik)," Toleransi 1, no. 2 (2019): 184206.
}

dimaksudkan untuk mengungkapkan bagaimana perspektif Hadis mengenai apa, siapa dan bagaimana People of the Book. Terakhir, karya-karya yang menjelaskan People of the Book dengan rujukan kepada Alquran dan Hadis sekaligus atau mengkaji isu ini secara umum dalam Islam. $^{8}$ Pendekatan teologis dan hukum merupakan cara yang dominan dalam ketiga kategori karya-karya ini dalam mengungkapkan apa, siapa dan bagaimana People of the Book itu.

Tidak diragukan lagi bahwa karya-karya dalam dua kategori di atas telah memberikan wawasan dan kontribusi yang sangat berharga bagi pemahaman yang lebih baik mengenai People of the Book. Meskipun demikian, tampak karya-karya tersebut lebih fokus pada upaya menjelaskan isu-isu tentang People of the Book semata dengan mengabaikan bagaimana mengaitkannya dengan isu-isu kontemporer atau menyimpannya dalam bingkai atau konteks tantangan yang dihadapi masyarakat dunia sekarang seperti globalisasi dan dampaknya. Akibatnya, tanpa menafikan kontribusi positifnya bagi pemahaman lebih baik mengenai People of the Book, karya-karya tersebut sepertinya belum memberikan jawaban atas tantangan dan problem yang dihadapi masyarakat modern.

7 Umi Sumbulah, "Islam Dan Ahl Al-Kitāb: Kajian Living Sunnah Di Kalangan Pimpinan NU, Muhammadiyah Dan Hizbut Tahrir Malang," AlTahrir: Jurnal Pemikiran Islam 11, no. 1 (2011): 151-71. Lihat juga Salamah Noorhidayati, "Relasi Antar Umat Beragama Dalam Perpektif Hadits," Kalam 10, no. 2 (2017): 491-516. Lihat Ja'far Assagaf, Hubungan Muslim Dengan Non Muslim Dalam Perspektif Hadis, Disertasi Doktoral, Sekolah Pascasarjana (UIN Jakarta, 2008).

${ }^{8}$ Muhammad Azizan Sabjan and Noor Shakirah Mat Akhir, "The Concept of the People of the Book (Ahl Al-Kitab) in Islamic Religious Tradition," AFKAR: Jurnal Akidah \& Pemikiran Islam 6, no. 1 (2005): 15-36. Lihat juga John L Esposito, Ahl AlKitab, The Oxford Dictionary of Islam (Oxford: Oxford University Press, 2014). Lihat juga Moshe Halbertal, People of the Book: Canon, Meaning, and Authority (Cambridge: Harvard University Press, 1997). 
Karena itu, artikel ini berupaya untuk mengisi celah dalam literatur tersebut dengan menganalisis People of the Book dalam perspektif Alquran dengan menjadikannya sebagainya jawaban atau solusi konstruktif bagi persoalan pluralisme keagamaan, sebuah persoalan nyata yang dihadapi oleh manusia sejak lama, tetapi semakin mengemuka di zaman modern ini melalui fenomena globalisasi.

Untuk tujuan itu, pada bagian-bagian selanjutnya, artikel ini akan mendeskripsikan temuannya tentang: pertama, ide-ide keagamaan People of the Book di Mekah; kedua, cara keberagamaan yang eksklusif; ketiga, kesatuan dalam keragaman; keempat, pluralitas sebagai prinsip dasar Alquran; kelima, pandangan positif Alquran terhadap agama-agama; dan terakhir kesimpulan.

\section{B. HASIL DAN PEMBAHASAN}

\section{Ide-ide Keagamaan People of the Book di Mekah}

Istilah "ahl al-kitab" (People of the Book) dalam Alquran disebut sebanyak 32 kali dalam 32 ayat dan 9 surat. ${ }^{9}$ Berdasarkan kronologi turunnya surat, satu ayat turun pada periode Mekah akhir dan yang lainnya sebanyak 31 ayat turun pada periode Madinah. ${ }^{10}$ Secara garis besar, keseluruhan ayat tersebut merekam sikap oposisi yang dilancarkan ahl al-kitab, tepatnya sebagian ahl al-kitab seperti yang akan dijelaskan di bawah, terhadap Alquran, Nabi Muhammad dan kaum Muslim dan menjelaskan respon Alquran terhadap oposisi ahl al-kitab tersebut. Pada ayat-ayat itu tampak suatu proses dialektika antara ahl al-kitab dan Alquran.

\footnotetext{
${ }^{9}$ Lihat daftar ayat yang mengandung istilah ahl alkitab pada lampiran artikel ini. Penyusunan kronologi ayat ini didasarkan pada susunan kronologis Gustav Weil dalam Montgomery Watt and Richard Bell, Pengantar Studi Alquran, trans. Taufik Adnan Amal (Jakarta: PT Raja Grafindo Persada, 1995), 307-309.

${ }^{10}$ Diskursus tentang kronologi turunnya ayat di kalangan sarjana Muslim, Manna Khalil Al-Qattan, Mabahis Fi Ulum Al-Quran Edisi Indonesia, Studi IlmuIlmu Quran, trans. Muzakir (Jakarta: Pustaka Litera Antar Nusa, 2000). Dan teori kesarjanaan Barat tentang
}

Menurut kronologi turunnya ayat, istilah ahl al-kitab disebut pertama kali dalam surat al-Ankabut/29:46. Ini berarti bahwa ayat ini diturunkan pada periode Mekah akhir dan satu-satunya ayat tentang ahl alkitab pada periode ini. Ayat ini menunjukkan bagaimana sikap yang harus diambil oleh kaum Muslim ketika menghadapi oposisi ahl al-kitab Mekah terhadap kedatangan Islam. Yakni, tidak bertindak ofensif ekstrim dan konfrontasi dan berupaya mendekati mereka untuk berdialog bahwa Taurat, Injil dan Alquran serta kitab suci lainnya merupakan wahyu Allah yang harus diimani dan kita samasama menyembah Tuhan Yang Satu. Dalam ungkapan lain, ada kesatuan wahyu dan kesatuan Ilahi dalam agama yang dibawa oleh Nabi Muhammad dan agama ahl alkitab yang datang sebelumnya. Ahl al-kitab dalam ayat tersebut diidentifikasi oleh alMaragy sebagai "sebagian orang-orang Yahudi dan orang-orang Nasrani" tanpa memberikan penjelasan lebih detail siapa mereka. ${ }^{11}$

Karena satu-satunya ayat yang mengandung istilah ahl al-kitab pada periode Mekah, ayat di atas merupakan respon pertama Alquran atas sikap oposisi ahl al-kitab terhadap Nabi dan kaum Muslim awal. Ini berarti sudah terjadi kontak keagamaan antara orang-orang Islam dan orang-orang Yahudi-Nasrani dan lebih jauh adanya ide-ide keagamaan mereka di antara komunitas Arab Mekah sebelum kedatangan Islam. Hal ini perlu dikemukakan sehubungan dengan pandangan beberapa orientalis, misalnya, W. Montgomery Watt, ${ }^{12}$ yang tanpa bukti-

penanggalan Alquran Watt and Richard Bell, Pengantar Studi Alquran.

${ }^{11}$ Ahmad Mustafa Al-Maragy, Tafsir Al-Maragy (Beirut: Dar al-Fikr, 1974), 5. Sejauh ini belum ada keterangan yang memadai tentang siapa YahudiNasrani di Mekah. Mungkin ini memerlukan kajian historis dan sosiologis yang serius, yang bukan tempatnya pada artikel ini, untuk mengungkap hal ini.

${ }^{12}$ W. Montgomery Watt, Muhammad's Mecca (Edinburgh: Edinburgh University Press, 1988), 4446. 
bukti yang jelas mengatakan bahwa ide-ide keagamaan Yahudi-Nasrani umumnya sudah ada di dalam milieu Arab, terutama di kota Mekah. Bila diandaikan ada ide-ide YahudiNasrani dalam komunitas Arab di Mekah, maka pertanyaannya adalah apakah di dalam dan di sekitar kota Mekah pada masa itu ada populasi ahl al-kitab?

Bahwa terdapat ide-ide keagamaan YahudiNasrani dalam masyarakat Arab Mekah dan banyak orang-orang Arab Mekah masa itu yang diajak ahl al-kitab untuk menganut agama mereka jelas terlihat dalam ayat-ayat Alquran seperti surat an-Naml/27: 67-68. Kalimat yang terjemahannya "kepada kami dan bapak-bapak kami hal ini telah dijanjikan di masa lampau (laqad wu'idna haza nahnu wa abauna min qablu) dapat menjelaskan bahwa orang-orang Yahudi dan orang-orang Nasrani pernah mencoba menarik orang-orang Arab Mekah ke dalam agama-agama mereka. Tuduhan kaum musyrikin Arab yang berulang kali dilontarkan bahwa Alquran hanyalah dongeng orang-orang zaman dahulu (al-Anfal/8:31) adalah bukti yang nyata bahwa orang-orang Arab telah mengenal ajaran-ajaran tradisi Yahudi-Nasrani yang dalam banyak hal terdapat kesamaannya dengan ajaran yang dibawa oleh Nabi Muhammad.

Selanjutnya, Alquran juga memberikan keterangan adanya populasi ahl al-kitab di Mekah dalam Surat al-An'am/6:9. Potongan ayat yang terjemahannya "Siapakah yang menurunkan kitab yang disampaikan Musa sebagai cahaya dan petunjuk yang kalian salin ke dalam lembaran-lembaran kertas" sudah pasti bukan ditujukan kepada orang-orang Arab Jahiliyyah ataupun kaum Muslim, melainkan lebih tepat ditujukan kepada orang-orang Yahudi. Orang-orang Yahudi yang mana? Ayat ini secara keseluruhan diturunkan di Mekah dan secara bersamaan ditujukan kepada orangorang Yahudi dan orang-orang Arab Mekah. Ini berarti orang Yahudi yang dimaksud adalah orang-orang Yahudi yang telah menyampaikan agama Musa kepada orang-orang Arab Mekah

${ }^{13}$ Fazlur Rahman, Tema Pokok Alquran (Bandung: Mizan, 2017), 220. yang dituju ayat di atas dan juga nenek moyang mereka.

Meskipun begitu, menurut Fazlur Rahman, ${ }^{13}$ tidak bisa dikatakan terdapat populasi orang-orang Yahudi dalam jumlah besar di Mekah. Yang mungkin terjadi adalah adanya kontak keluarga antara beberapa orang Yahudi Mekah yang sering dikunjungi oleh orang Yahudi lainnya dari Madinah. Mungkin juga dalam konteks hubungan bisnis para pedagang Mekah mengunjungi keluarga mereka di Madinah dan berdiskusi dengan orang-orang Yahudi dan mungkin pula dengan orang-orang Nasrani. Ibn Ishaq, pengarang buku sejarah Sirah, ${ }^{14}$ mensinyalir hubungan di antara mereka terjadi secara sistematis. Dengan maksud untuk mencegah menyebarnya ajaran-ajaran yang dibawa oleh Nabi Muhammad, orang-orang Mekah mengutus An-Nadhar bin al-Haris dan Uqbah bin Abi Mu'ait ke Madinah untuk berkonsultasi dengan orang-orang Yahudi bagaimana cara untuk mengalahkan Nabi Muhammad dalam perdebatan-perdebatan. Ibn Haris sangat ahli dalam legenda-legenda Persia. Setiap kali Nabi Muhammad selesai menyampaikan dakwahnya, membacakan Alquran dan menerangkan nasib yang menimpa kepada kaum-kaum di zaman dahulu kepada masyarakat Quraisy, naiklah An-Nadhr mengisahkan legenda-legenda Persia kuno. Setelah itu, ia mengatakan bahwa sehubungan dengan keahliannya dalam kisah-kisah kaum zaman dahulu ia mengaku bisa menjadi seperti Muhammad. Hal ini dengan jelas membuktikan bahwa adanya ide-ide Yahudi-Nasrani di kalangan masyarakat Arab Mekah yang mereka pelajari atau menerimanya dari orang-orang Yahudi-Nasrani yang berada di Mekah atau di luar Mekah.

Selain itu, Alquran menerangkan ada beberapa orang Yahudi atau mungkin pula orang Nasrani yang telah menghidupkan harapan-harapan Messianik. Ketika Nabi Muhammad tampil, mereka mendukung

14 Fazlur Rahman, Tema Pokok Alquran. Lihat juga Ibn Ishaq, Al-Sirah Al-Nabawiyyah (Kairo: Darul Kutub al-Misriyah, t.th). 
beliau dalam menyampaikan ajaran-ajarannya dan mempercayai risalah yang disampaikannya. Mereka inilah yang dijuluki sebagai "orang-orang yang telah diberi pengetahuan". Ketika masyarakat menuntut bukti dari Nabi Muhanunad bahwa beliau memang rasul Allah, Alquran menjawab: "Dan apakah tidak cukup menjadi bukti bagi mereka bahwa orang-orang yang berilmu di kalangan Banu Israel mengetahuinya"(alSyu'ara/26:197). Kemudian, Alquran membuat perbedaan yang tegas di antara mereka ini dengan orang-orang Yahudi secara umum yang tidak mempercayai Alquran yang disebut sektarian-sektarian (ahzab) dalam Hud/ll:17. Hal yang senada ditemukan pula pada al$\mathrm{Ra}$ 'd/13:36 dan al-Ankabut/29:47 yang semuanya termasuk dalam kronologi periode Mekah.

\section{Oposisi People of the Book terhadap Nabi Muhammad}

Ketika Nabi Muhammad dan kaum Muslim memasuki Madinah (622 AD), di sana sudah terdapat komunitas Arab yang menjadi penduduk asli. Aws dan Khazraj merupakan komunitas besar dan suku utama Madinah. Di samping suku Arab asli ini, juga terdapat populasi People of the Book (ahl al-kitab), yakni Yahudi-Nasrani, yang membangun koloni di pinggiran kota Madinah. Yang terakhir ini memperlihatkan sikap tidak senang atas kedatangan agama yang dibawa oleh Nabi Muhammad. Dengan berbagai cara, dari penyebaran fitnah sampai percobaan untuk membunuh Nabi, mereka melakukan oposisi terhadap Nabi dan kaum Muslim. Tujuannya adalah menghambat penyebaran Islam di kalangan masyarakat Madinah.

Setidaknya, terdapat dua alasan yang menjadi pemicu sikap oposisi People of the Book terhadap Nabi Muhanunad dan kaum Muslim.

Pertama, kepentingan ekonomi-politik. Orang-orang Yahudi --komunitas agama yang diidentifikasi sebagai People of the Book sesuai dengan makna konteks ayat-ayat mengandung istilah tersebut, di samping orang-orang Nasrani-- tidak menghendaki masyarakat Madinah, yang multi suku, bersatu untuk mempertahankan dominasi politik mereka. Di tengah perpecahan masyarakat Madinah, terutama perseteruan suku terbesar Aws dan Khazraj, komunitas Yahudi muncul menjadi kekuatan yang dominan secara politik. Hal ini disebabkan keberhasilan mereka mengorganisir diri menjadi golongan yang kuat secara politik dan ekonomi. Secara ekonomi, orang Yahudi dikenal sebagai pedagang dan kaum kapitalis. Mereka menguasai kapital dengan menerapkan sistem pinjaman yang bunganya berlipat-lipat. $\mathrm{Di}$ tengah perpecahan politik dan ketidakberdayaan ekonomi ini, masyarakat Madinah mengalami semacam ketergantungan kepada orang-orang Yahudi dan berada di bawah dominasi mereka. Ketika Islam datang, Nabi Muhammad berhasil mempersatukan masyarakat Madinah dalam ikatan persaudaraan Islam dan secara ekonomi semakin membaik, misalnya, dengan banyaknya perolehan harta rampasan perang. Situasi seperti ini jelas tidak menguntungkan bagi komunitas Yahudi yang pada gilirannya memudarnya dominasi ekonomi dan politik mereka di kalangan masyarakat Madinah. Maka, yang terjadi adalah orang-orang Yahudi mengadakan oposisi terhadap Nabi dan kaum Muslim untuk merebut kembali dominasi mereka atas penduduk Madinah yang kini, dalam pandangan mereka, diambil oleh Nabi. ${ }^{15}$

Hal yang sama terjadi pula pada kaum Nasrani. Mereka menyadari kebenaran Nabi Muhammad dan agama yang dibawanya sebagaimana ihwal kedatangannya sudah tertulis dalam kitab suci mereka. Namun, karena takut kehilangan harta kekayaan dan pengaruh yang selama ini mereka terima dari imperium Romawi, mereka tidak mengakui secara formal kerasulan Muhammad dan

\footnotetext{
${ }^{15}$ Madjid Ali Khan, Muhammad the Final Messenger (Delhi: Idarah-i Adabiyat-i Delhi, 1980), 105-106.
} 
kebenaran wahyu yang diterimanya. Abu Haris, salah seorang tokoh terpelajar Nasrani, berkata: "Apa yang mencegah kami untuk mengakui kebenaran Muhammad adalah apa yang telah diperbuat orang-orang Romawi kepada kami; mereka telah memberi kami kehormatan, membuat kami kaya, dan mempunyai pengaruh. Jika kami menentang mereka, maka semua ini akan diambil kembali." 16

Kedua, cara keberagamaan yang eksklusif. Hal ini berakar pada doktrin Yahudi bahwa anak-keturunan Israel adalah hamba terpilih Tuhan sebagai penerima wahyu-Nya dan kekasih Tuhan. Ajaran Taurat adalah eksklusif bagi anak-keturunan Israel. Ada semacam nasionalisasi agama Musa pada anak-keturunan Israel. Inilah yang akan dielaborasi lebih jauh dengan merujuk ayat-ayat People of the Book.

Pada periode Madinah, istilah "People of the Book" (ahl al-kitab) muncul pertama kali dalam al-Baqarah/2:105. Menurut al-Wahidy, ayat ini turun ketika orang-orang Yahudi diseru oleh kaum Muslim untuk mempercayai Muhammad sebagai rasul Allah, mereka menjawab bahwa apa yang diserukan itu bukanlah kebaikan yang selama ini didambakan dari Tuhan. ${ }^{17}$ Kebaikan (khair) pada ayat di atas ditafsirkan oleh al-Maragy sebagai "Alquran yang merupakan kebaikan yang paling besar karena berisi petunjukpetunjuk agung". ${ }^{18}$ Dikatakan kebaikan karena Alquran manyatukan suku-suku dan bangsabangsa yang berbeda dalam semangat kebersamaan, mensucikan hati dan akal dari pengaruh paham paganisme dan telah mengkokohkan manusia kembali pada fitrahnya.

Pada pokoknya, ayat tersebut menjelaskan sikap oposisi sebagian masyarakat Yahudi Madinah dan orang-orang musyrik yang tidak menginginkan diwahyukannya Alquran kepada Muhammad. Mereka beranggapan wahyu dan

16 Tahia Al-Ismail, The Life of Muhammad: His Life Based on the Earliest Source (London: Ta-Ha Publisher, 1993), 128. Lihat juga Syeikh Tantawi Jauhari, AlJawahir Fi Tafsir Al-Qur'an Al-Karim (Beirut: Dar alFikr, 1900), 128. kenabian merupakan eksklusif milik Banu Israel sebagai hamba Tuhan yang terpilih. Akibatnya, ketika Alquran diwahyukan dan Muhammad diangkat sebagai rasul Allah, mereka menentangnya dan mengatakan itu bukan kebaikan dari Allah sebagaimana yang diberikan kepada mereka.

Ayat senada kita temukan pada surat alNisa/4:153, "Ahl al-kitab meminta kepadamu agar kamu menurunkan kepada mereka sebuah kitab dari langit..." Tanpa penjelasan lebih detail, al-Wahidy mengidentifikasi ahl al-kitab pada ayat di atas sebagai orang-orang Yahudi Madinah yang berkata kepada Nabi: "Jika engkau memang benar seorang nabi Allah datangkanlah kepada kami kitab secara sekaligus seperti yang diterima Musa". ${ }^{19}$ Menurut riwayat Ibn Jarir dari Ibn Juraij, orang-orang Yahudi berkata kepada Nabi: "Kami tidak akan mengakui terhadap apa yang engkau dakwahkan kepada kami (baca: Alquran) kecuali engkau mendatangkan kepada kami kitab dari sisi Tuhan yang di dalamnya tertulis; dari Tuhan kepada fulan, sesungguhnya engkau rasul Allah." ${ }^{20}$ Sikap mereka seperti ini tidak lain dimaksudkan untuk menentang kebenaran Alquran sebagai wahyu Allah, bukan mencari bukti-bukti yang bisa menambah keyakinan.

Sikap eksklusif kaum Yahudi dalam keberagamaan ini, yang pada gilirannya melahirkan sikap tidak mau menerima kebenaran dari komunitas atau agama lain di atas, mendapatkan tanggapan dari Allah sebagaimana termaktub pada alHadid/57:29. Persoalan pewahyuan kitab dan menentukan siapa yang berhak menerimanya adalah berada dalam kekuasaan dan kehendak Allah. Tidak seseorang atau suatu kaum pun, termasuk Banu Israel, yang bisa mencegah atau

\footnotetext{
17 Abu al-Hasan Aly bin Ahmad Al-Wahidy, Asbab Al-Nuzul (Beirut: al-Maktabah al-
} Tsaqafiyyah, 1989), 18.

\footnotetext{
${ }^{18}$ Al-Maragy, Tafsir Al-Maragy, 185.

${ }^{19}$ Al-Wahidy, Asbab Al-Nuzul, 106.

${ }^{20}$ Al-Maragy, Tafsir Al-Maragy, 9.
} 
mendorong-Nya untuk menurunkan sebuah kitab atau tidak menurunkannya; "...Dan Allah menentukan siapa yang dikehendaki-Nya (untuk diberi) rahmat-Nya (kenabian)..." (alBaqarah/2:105). Mengklaim wahyu Tuhan eksklusif bagi anak-keturunan tertentu seperti anggapan orang-orang Yahudi berarti berusaha membatasi kehendak dan kemahakuasaan Allah yang tidak terhingga. Mewahyukan Alquran kepada Muhammad adalah bagian dari kehendak dan kemahakuasaan-Nya. Jadi, dengan ini Alquran 'mengkritik' kecenderungan ekslusif dalam keberagamaan dan nasionalisme agama di kalangan orang-orang Yahudi yang mengakibatkan tidak bisa melihat kebenaran dalam agama wahyu lainnya.

Surat al-Nisa/4:123 juga menjelaskan respon Alquran terhadap sikap orang-orang Yahudi tersebut. Ada keterangan yang menarik perihal sebab turunnya ayat tersebut berupa riwayat dari Masruq dan Qatadah:

Kaum Muslim berdebat dengan People of the Book, yang berkata: "Kami lebih mendapat petunjuk daripada kalian; nabi kami datang sebelum nabi kalian; kitab kami turun sebelum kitab kalian dan kami lebih utama di sisi Allah daripada kalian". Kaum Muslim pun menjawab: "Kamilah yang lebih mendapat pahala dan lebih utama di hadapan Allah; nabi kami penutup para nabi dan kitab kami hakim bagi kitab-kitab sebelumnya." 21

Melihat sabab an-nuzul di atas, ayat ini turun sebagai koreksi terhadap anggapan People of the Book dan kaum Muslim yang membenarkan agamanya masing-masing dengan cara menyalahkan agama lain. Pahala dan kebenaran tidak akan diperoleh melalui sikap berbangga-bangga dengan agamanya dan keberagamaan eksklusif. Dalam mengomentari ayat ini, al-Maragy mempunyai komentar yang menarik:

Keutamaan dan kemuliaan suatu agama serta keselamatan pemeluknya bukanlah dengan berkata "agamaku lebih utama dan mulia daripada agamamu", melainkan dengan beramal sesuai dengan petunjuk agama itu. Karena pahala diperoleh dengan beramal bukan dengan angan-angan dan tipu daya.

\footnotetext{
${ }^{21}$ Al-Maragy, Tafsir Al-Maragy, 103-104.
}

Keselamatan kalian dan keselamatan People of the Book tidak tergantung pada angan-angan dalam beragama. Agamaagama tidak disyariatkan untuk berbanggabangga dan manfaat agama-agama tidak akan diperoleh tanpa mengamalkannya. ${ }^{22}$

Setelah orang-orang Yahudi berusaha menentang kebenaran Alquran dengan berlindung pada eksklusivisme keberagamaan dan nasionalisme agama, kemudian dengan pola yang sama mereka mempertanyakan kenabian Muhammad. Hal ini dijelaskan dalam al-Bayyinah/98:13.

Sebagian orang-orang Yahudi dan Nasrani dan orang-orang musyrik menentang Muhammad dan mengingkari kenabiannya padahal berita akan kedatangannya tercantum dalam kitab-kitab mereka. Mereka akan tetap dalam pandangan dan sikap mereka seperti ini sampai Muhammad datang kepada mereka dengan membawa lembaran-lembaran Alquran yang suci dari penyimpangan dan pemalsuan sebagai bukti nyata kerasulannya. Tapi, mereka sebenarnya tidak mengharapkan bukti tersebut, melainkan bermaksud membuktikan kebohongan Muhammad dan kepalsuan agama yang dibawanya. Surah Ali Imran/3:72 menjelaskan sinyalemen tersebut.

Riwayat berikut ini menjelaskan ayat di atas dan sekaligus menjadi latar belakang diwahyukannya:

Al-Hasan dan al-Suda berkata: Dua belas orang pendeta Yahudi mengadakan kesepakatan. Sebagian di antara mereka berkata kepada yang lainnya: "Masuklah kalian kepada agama Muhammad pada pagi hari dengan lisan tanpa disertai keyakinan dan ingkarlah pada sore hari. Kemudian katakanlah (kepada pengikut Muhammad); "Setelah kami memperhatikan kitab kami dan pemimpin agama kami pun bersepakat, kami mendapati Muhammad bukan seperti dalam kitab kami dan pandangan pemimpin agama kami. Jelas bagi kami kebohongan

${ }^{22}$ Al-Maragy, Tafsir Al-Maragy, 165. 
Muhammad dan kepalsuan agamanya." Jika kalian melakukan ini niscaya pengikut Muhammad menjadi ragu akan agama yang mereka peluk dan akan berkata: "Mereka itu People of the Book (ahl al-kitab) dan mereka pasti lebih tahu daripada kita". Lantas, mereka berpaling dari agama mereka kepada agama kalian. $^{23}$

Selanjutnya, pada al-Maidah/5:15 dan 19 kita membaca respon Alquran menanggapi sikap orang-orang Yahudi tersebut. Di sini, Allah mengatakan kepada orang-orang Yahudi dan orang-orang Nasrani bahwa Muhammad itu rasul Allah yang membawa Alquran seperti Musa dengan Tauratnya dan Isa dengan Injilnya. Muhammad datang untuk membeberkan sebagian ajaran Taurat dan Injil yang selama ini disembunyikan atau dirubah seperti hukum rajam bagi penzina, berita penghisaban amal dan balasan di akhirat dan berita kedatangan rasul Tuhan yang terakhir. Pada ayat ini, kerasulan Muhammad ditegaskan kebenarannya. Bila mereka masih mengingkari kebenaran yang jelas ini padahal mereka mengetahuinya sebagaimana mengetahui nabinabi mereka, maka Allah akan menimpakan kepada mereka balasan kepada mereka (alBayyinah /98: 6).

Bukan hanya kewahyuan Alquran dan kerasulan Muhammad yang menjadi sasaran oposisi komunitas Yahudi, melainkan juga kaum Muslim. Mereka menganggap pengikut Muhammad telah keliru mempercayai Muhammad dengan Alqurannya sebab bagi mereka Muhammad bukanlah rasul Tuhan dan Alquran bukan kitab yang diwahyukan Tuhan. Oleh karena itu, sebagian orang-orang Yahudi dengan motif ekonomi-politik dan perasaan dengki (baca: keberagamaan yang eksklusif) seperti diuraikan di atas berusaha untuk memalingkan kembali pengikut Nabi Muhammad dari keimanannya dan beralih kepada agama mereka. Alquran surat alBaqarah/2:109 dengan jelas merekam peristiwa ini.

${ }^{23}$ Al-Wahidy, Asbab Al-Nuzul, 162.

24 Imaduddin Abi al-Fida Ismail bin Kasir AlDimasqy, Mukhtasar Tafsir Ibn Kasir, ed. Muhammad Al-Sabuny (Kairo: Dar al-Turas al-Araby, 1987), 106.
Sebuah keterangan Ibn Abbas berikut ini bisa menambah kejelasan maksud ayat ini:

Huyayy bin Akhtab dan Abu Yasir bin Akhtab adalah termasuk di antara orangorang Yahudi yang paling iri ketika Muhammad dipilih Allah menjadi rasulNya. Keduanya berusaha keras memalingkan masyarakat dari Islam. Sehubungan dengan upaya keduanya, turunlah ayat al-Baqarah/2:109. ${ }^{24}$

Keinginan sebagian orang-orang Yahudi untuk memalingkan kaum Muslim dari Islam dan berusaha menarik mereka kepada agama mereka, kita temukan pula pada Ali Imran/3:69: "Segolongan dari ahl al-kitab ingin menyesatkan kalian padahal mereka (sebenarnya) tidak menyesatkan melainkan dirinya sendiri tetapi mereka tidak menyadarinya." Sikap mereka terhadap kaum Muslim seperti itu tidak hanya tampak pada persoalan keberagamaan saja, melainkan pada masalah hubungan kemasyarakatan pun mereka bersikap serupa. Tentang amanat harta, misalnya, mereka cenderung mengingkarinya. Hal ini mereka lakukan dengan berlindung pada anggapan bahwa agama mereka tidak melarang mengambil harta orang-orang di luar kumunitas mereka meskipun dengan cara yang tidak sah. Di sini, mereka memperlihatkan kembali eksklusivisme dan superioritas anak-keturunan Israel. Sikap mereka ini termaktub dalam Ali Imran/3:75.

\section{Kesatuan dalam Keragaman: Inklusivisme Alquran}

Suatu ketika, utusan Nasrani Najran datang ke Madinah dan bertemu dengan orang-orang Yahudi. Kemudian mereka berselisih pendapat tentang Nabi Ibrahim. Orang-orang Nasrani menganggap Ibrahim adalah seorang yang beragama Nasrani dan karena itu mereka beragama dengan agamanya dan paling utama tentang agama Ibrahim. Kemudian orang-orang Yahudi berkata: "Tidak, Ibrahim bukan seperti itu. 
Ia seorang Yahudi dan kami pengikut agamanya yang paling utama". Kemudian, Rasulullah Muhammad berkata kepada mereka: "Kalian tidak ada hubungan dengan Ibrahim. Ibrahim adalah seorang yang selalu cenderung kepada kebenaran (hanif) dan seorang yang berserah diri (muslim). Karena itu, ikutilah agamanya, yaitu Islam". Orangorang Yahudi berkata: "Wahai Muhammad, bukankah dengan berkata begitu kamu menginginkan kami untuk menjadikan kamu sebagai Tuhan seperti orang-orang Nasrani menjadikan Isa sebagai Tuhan?". Orang-orang Nasrani pun berkata: "Wahai Muhammad, bukankah dengan berkata begitu kamu menginginkan kami mengatakan tentang kamu seperti apa yang dikatakan orang-orang Yahudi tentang Uzair?." 25

Tuturan di atas, dalam pandangan para mufassir merupakan latar belakang diwahyukannya (sabab al-nuzul) ayat 64 dari Surah Ali Imran:

Katakanlah: '"Hai ahl al-kitab, marilah (berpegang) kepada suatu kalimat (ketetapan) yang tidak ada perselisihan antara kami dan kalian bahwa tidak kita sembah kecuali Allah dan tidak kita persekutukan Dia dengan siapapun dan tidak (pula) sebagian kita menjadikan yang lain sebagai tuhan selain Allah. Jika mereka berpaling, maka katakanlah kepada mereka:"Saksikanlah bahwa kami adalah orang-orang yang berserah diri (kepada Allah)."

Menurut kronologis turunnya surat, ${ }^{26}$ ayat tersebut merupakan respon pertama Alquran terhadap oposisi People of the Book (ahl alkitab) dalam periode Madinah. Pada sabab alnuzul di atas, tampak Nabi Muhammad menginginkan sekali orang-orang Yahudi dan Nasrani mengikuti agama Islam yang dibawanya. Ini beliau lakukan dengan cara mengajak mereka berdebat dan mengemukakan argumen-argumen tentang kebenarannya. Di antaranya, Nabi mengajukan argumen bahwa Islam mempunyai hubungan originalitas dengan Nabi Ibrahim. Namun, argumen ini

25 Abu Muhammad al-Husein bin Mas'ud al-Farra' Al-Bagawy, Ma'alim Al-Tanzil Fi Al-Tafsir-Wa AlTawil (Beirut: Dar al-Fikr, 1985), 482.

${ }^{26}$ Lihat lampiran. malah dijadikan alasan oleh mereka untuk mengatakan bahwa Muhammad ingin dianggap sebagai Tuhan. Artinya, beradu argumen dengan mengemukakan sesuatu yang manjadi keunggulan Islam dan menunjukkan kekurangan agama mereka bukanlah cara yang terbaik malah semakin membuat mereka meningkatkan oposisi dan sikap tidak bersahabat terhadap Islam. Dalam konteks ini, ayat tersebut memberikan cara terbaik yang bisa digunakan untuk menghadapi sikap Yahudi-Nasrani. Yaitu, mengajak mereka kepada hal yang menjadi kalimah sawa (titik-temu) yang bisa menyatukan ketiga agama tersebut. Dalam ungkapan Fakhruddin al-Razy, seakan-akan Allah berkata begini: "Wahai Muhammad, tinggalkanlah cara tersebut dan beralihlah kepada cara lain di mana orang yang berakal sehat dan berjiwa mantap menyaksikan, yaitu ucapan yang berpijak pada kesamaan dan jauh dari perbantahan". ${ }^{27}$ Dengan demikian, Alquran menyuruh Nabi Muhammad dan kaum Muslim untuk lebih menekankan pencarian kesamaan ketiga agama Ibrahim tersebut walaupun dengan tetap mempertahankan adanya perbedaanperbedaaan yang menjadi kekhasan masingmasing.

Di sini, terasa sekali uluran tangan yang bersahabat dan sikap penuh simpatik Alquran. Hal ini pertama-tama terlihat pada pengunaan istilah ahl al-kitab pada ayat tersebut. Istilah ahl al-kitab merupakan salah satu sebutan yang paling baik dan panggilan yang paling sempurna karena Allah menjadikan mereka sebagai pembawa kitab-Nya, seperti dikatakan kepada penghafal Alquran (huffaz) sebagai pembawa kitab Allah dan kepada mufassir sebagai penafsir kalam Allah. Sebutan ini menunjukkan bahwa pembicaranya ingin menghormati yang diajak bicara dan menyenangkan hatinya. Sebutan ini digunakan untuk menghindari cara-cara

27 Muhammad al-Razy Fakhruddin ibn alAllamah Diya ad-Din Umar, Mafatih Al-Gayb (Beirut: Dar al-Fikr, 1981), 94. 
permusuhan dan pertentangan menuju cara pencarian kesamaan. ${ }^{28}$ Selanjutnya, titik-temu yang harus dikemukakan dan kesamaan yang harus diungkapkan antara ketiga agama Ibrahim tersebut dapat kita baca kalimatkalimat selanjutnya pada ayat yang sama: pertama, hanya Allah yang layak disembah; kedua, tidak mensekutukan-Nya dengan sesuatu yang lain; dan ketiga, tidak menjadikan seseorang atau kelompok tertentu sebagai Tuhan selain Allah.

Ketika menyebutkan ketiga hal tersebut di atas, Alquran menjelaskannya dalam konteks agama-agama monoteisme. Pada ajaran agamaagama wahyu, monoteisme menjadi inti ajaran. Karena memandang ahl al-kitab sebagai pemilik agama wahyu Allah, maka Alquran mengajak mereka kepada common term agama Allah: monoteisme murni. Kepada inti ajaran inilah sebenarnya penganut Yahudi dan Nasrani diajak untuk mencari titik-temu dan mengamalkannya secara murni. Selain sebagai ajakan, hal ini juga merupakan koreksi kepada Yahudi dan Nasrani yang telah menyimpang dari ajaran monoteisme Ibrahim. Yakni, kaum Yahudi telah menganggap Uzair sebagai anak Allah dan kaum Nasarani telah menyembah Isa selain Allah dan mengatakan Allah itu ada tiga oknum: Tuhan Bapak, Tuhan Anak dan Ruh alQuds dan menjadikan pendeta-pendeta mereka sebagai tuhan-tuhan. Jadi, seruan kepada kalimah sawa berarti ajakan kepada kaum Yahudi dan Nasrani untuk kembali kepada monoteisme murni sebagaimana monoteisme agama Ibrahim yang diklaim sebagai asal-usul agama mereka yang sekaligus pula di situ terletak kalimah sawa (titik-temu) antara Yahudi, Nasrani dan Islam. Inilah sebabnya ketiga agama ini disebut agama-agama Ibrahimy (Abrahamic Religions).

Seruan kepada titik-temu ini menjadi menarik dilihat dari kronologis surat bahwa Ali Imran/3:64 di atas merupakan respon pertama Alquran terhadap oposisi ahl al-kitab pada periode Madinah. Bahkan, sebenarnya respon Alquran seperti ini sudah muncul pada ayat pertama yang mengandung istilah ahl al-kitab pada periode Mekah akhir sebagaimana telah diuraikan pada awal bab ini: "... Dan katakanlah: "Kami telah beriman kepada (kitab-kitab) yang diturunkan kepada kami dan yang diturunkan kepada kalian; Tuhan kami dan Tuhan kalian adalah satu dan kami hanya kepada-Nya berserah diri." (alAnkabut/29:46). Terdapat kesamaan gagasan antara kedua ayat ini: seruan kepada titik-temu; monoteisme.

Sikap Alquran seperti ini bisa dikatakan 'aneh' bila menilik bahwa ia sebagai wahyu yang secara intrinsik mempunyai klaim kebenaran (truth claim) sendiri. Alquran memperlihatkan suatu cara keberagamaan yang inklusif bahwa terdapat kebenaran pada agama-agama wahyu lain. Ketika orang-orang Yahudi dan orang-orang Nasrani memperlihatkan sikap oposisi terhadap Islam dengan cara keberagamaan yang eksklusif, Alquran menjawabnya dengan ajakan mencari common term agama-agama tanpa menggugat validitas wahyu-wahyu lain. Dalam ungkapan lain, dari segi bentuk jelas agama-agama wahyu berbeda, tapi pada segi substansi (inti ajaran) di sana akan ditemukan kesatuan agama-agama. Yang pertama (dimensi bentuk) selalu menjadi pembenaran untuk tidak bersikap toleran terhadap agama lain dan membina hubungan harmonis antaragama. Kesatuanlah, tepatnya dimensi dalam yang menyatukan, yang harus dikedepankan dalam memahami pluralitas agama. Dalam pandangan Alquran, kesatuan tersebut adalah doktrin monoteisme (tauhid dalam istilah teologi Islam) yang menjadi inti agama-agama wahyu.

Satu hal yang dapat dipahami dari sikap positif Alquran tersebut adalah Alquran sebagai suatu wahyu mengakui wahyuwahyu lain sebelum Alquran sebagai valid. Ahl al-kitab yang dituju pada konteks ayat Ah Imran/3:64 di atas dan secara keseluruhan ayat-ayat yang mengandung istilah ahl al-kitab --seperti yang nampak

${ }^{28}$ Muhammad al-Razy Fakhruddin ibn al-Allamah Diya ad-Din Umar, 95. 
pada pembahasan di atas dan di bawah ini-adalah orang-orang Yahudi dan orang-orang Nasrani, dua komunitas agama wahyu (Taurat dan Injil) yang datang sebelum Islam. Hal ini disebabkan komunitas penganut agama wahyu yang hadir dan dikenal ketika Alquran diwahyukan dalam milieu Mekah dan Madinah adalah orang-orang Yahudi dan orang-orang Nasrani. Namun, secara substansial ahl al-kitab menjadi sebuah sebutan umum bagi orangorang yang menganut dan mempercayai kitabkitab wahyu atau wahyu suci tertulis lainnya (other holy writ). Penggunaan sebutan ahl alkitab untuk orang-orang Yahudi dan orangorang Nasrani karena adanya kepastian asal kitab-kitab suci mereka sebagai wahyu Tuhan. Validitas kewahyuan agama mereka tidak mesti berarti bahwa di dunia ini tidak ada $a h l$ al-kitab selain mereka karena diketahui bahwa Allah mengutus rasul dalam setiap umat dan komunitas untuk membawa berita gembira dan berita ancaman dan Dia menurunkan kitab suci kepada mereka. Oleh karena itu, dalam pandangan Rasyid Ridla, ahl al-kitab tidak saja berarti kaum Yahudi dan kaum Nasrani melainkan juga penganut Zoroaster, Sabi'in, Hindu, Budha, agama Cina dan agama Jepang yang diyakini memiliki kitab suci yang diwahyukan. ${ }^{29}$ Juga, Hamka, salah seorang ulama besar Indonesia dan pendiri Majlis Ulama Indonesia (MUI) sekaligus ketua pertama dan paling berpengaruh, mengatakan bahwa ajaran-ajaran Taoisme Cina adalah monoteisme sejati atau tauhid dan karena itu bisa dikatakan sebagai ahl al-kitab. ${ }^{30}$ Pengakuan Alquran tentang validitas wahyuwahyu Tuhan lainnya ini merupakan suatu hal yang luar biasa sepanjang sejarah agama sebagaimana diungkapkan oleh Cyril Glasse: "Fakta bahwa satu wahyu (Alquran) menyebut wahyu-wahyu lain sebagai otentik adalah peristiwa yang luar biasa dalam sejarah agamaagama". 31

\footnotetext{
${ }^{29}$ Muhammad Rasyid Ridla, Tafsir Al-Manar, Vol. 6 (Beirut: Dar al-Ma'rifah, tth), 188-189.

${ }^{30}$ Yunus Yahya, Muslim Tionghoa (Jakarta: Yayasan Ukhuwah Islamiyah, 1985), 6. Lihat juga Nurcholish Madjid, "Islamic Roots of Modern Pluralism: Indonesian
}

\section{Pluralisme Keagamaan: Prinsip Dasar Alquran}

Pada konteks ini, persoalan pluralitas (keragaman) agama adalah absah dan merupakan bagian dan kehendak Allah. Pluralitas agama ini didasarkan pada kenyataan bahwa masyarakat manusia bersifat plural secara sosio-kultural. Hal ini adalah hukum kemasyarakatan yang diberikan Tuhan (sunatullah). Masyarakat dalam dirinya sendiri terbagi ke dalam berbagai kelompok dan komunitas di mana masing-masing mempunyai orientasi kehidupannya sendiri yang memberi arah petunjuk. Apa yang diinginkan dari pluralitas tersebut adalah masyarakat dapat menerima kenyataan tentang adanya kemajemukan sosio-kultur dan saling toleran dalam memberikan kebebasan dan kesempatan kepada setiap orang untuk menjalani kehidupan sesuai dengan sistem kepercayaan masing-masing. Yang diharapkan dari kemajemukan tersebut adalah saling berlomba dalam hal yang dapat dibenarkan dengan cara yang sehat untuk mencapai sesuatu yang terbaik bagi semua. Perihal keputusan akhir terhadap apa yang diperbuat atau baik buruknya dalam artian final hanya Allah yang maha mengetahui (al-Baqarah/2:148, 213).

Pandangan tentang pluralitas ini tampak sebagai suatu yang mendasar dalam Alquran. Pluralisme dapat dipahami sebagai suatu "pertemuan yang sejati dari keserbaragaman dalam ikatan-ikatan kesopanan (bonds of civility)". ${ }^{32}$ Persoalannya, bukanlah bagaimana menghilangkan pluralitas pemeluk agama dan menyatukan dalam komunitas tunggal agama, melainkan bagaimana pluralitas tersebut menjadi pendorong untuk mengembangkan diri dan masyarakat dalam suatu 'kompetisi kebaikan' yang didasari niat mencari kebenaran. Plural berarti

Experience," Studia Islamika 1, no. 1 (2014), 31, https://doi.org/10.15408/sdi.v1i1.866.

${ }^{31}$ Cyril Glasse, The Concise Encyclopedia of Islam (London: Stacey International, 1989), 27-18.

32 Nurcholish Madjid, "Pluralisrne Agama Di Indonesia," Ulumul Qur'an 6, no. 3 (1995): 63. 
several (beberapa) yang menunjuk kepada heterogen, bukan many (beberapa) yang homogen.

Di sini, terletak apa yang disebut kebebasan individu untuk mengekspresikan agama yang dianutnya dan menjalani hidup sesuai sistem kepercayaan yang diyakininya. Karena itu, pemaksaan dan pendiktean agama atau kepercayaan merupakan suatu hal yang tidak mendapat tempat dalam dunia pluralitas. Menurut Alquran, pluralitas keagamaan merupakan persoalan komunitas manusia yang sudah menjadi hukum Tuhan (sunnatullah). Adalah hak Allah untuk menjelaskan nanti di akhirat mengapa manusia berbeda satu sama lain dalam hal agama daan yang lainnya (alMaidah/5:48).

Ahmad Mustafa al-Maragy, ketika menjelaskan ayat di atas, berkata: "Syariah atau Syir'ah --yang merupakan hukum-hukum amaliah-- berbeda-beda sesuai dengan perbedaan kondisi masyarakat dan watak manusia. Tetapi para rasul memiliki kesamaan dalam dasar agama: yaitu mengesakan Allah (tawhid) dan berserah kepada-Nya (al-Islam)." Selanjutnya dengan mengutip suatu riwayat, ia menambahkan: "Jalan hidup (minhaj) itu beragam; bagi Taurat ada syariah, bagi Injil ada syariah dan juga dalam Alquran ada syariah di mana Allah menetapkan yang halal dan yang haram sesuai dengan kehendak-Nya untuk mengetahui siapa yang taat dan siapa yang ingkar. Tetapi agama (din) yang dibawa para rasul adalah Tauhid dan ikhlas kepada Allah."33

Ungkapan "untuk tiap-tiap umat di antara kamu" menunjukkan kepada komunitaskomunitas atau kelompok-kelompok yang beragam di mana dengannya sistem masyarakat tersusun. Istilah syir'ah, yang secara tekstual berarti jalan menuju tempat berair, menurut Muhammad Asad, ${ }^{34}$ digunakan dalam Alquran untuk menunjuk pada sebuah sistem hukum yang sangat penting bagi kesejahteraan sosial dan spiritual sebuah komunitas. Sementara itu,

\footnotetext{
${ }^{33}$ Al-Maragy, Tafsir Al-Maragy, 130.

34 Muhammad Asad, The Message of the Qur'an (Gibraltar: Dar al-Andalus, 1980), 153-154.

${ }^{35}$ Muhammad Asad, The Message of the Qur'an.

36 Pembahasan tentang universalitas dan finalitas Islam lihat Marcia K. Hermansen, "Shah Wali Allah of
}

minhaj menunjukkan pada sebuah 'jalan terbuka' yang biasanya mengarah pada makna yang abstrak; yaitu 'jalan hidup'. Istilah syir'ah dan minhaj lebih terbatas penggunaannya bila dibandingkan dengan istilah din yang terdiri dari tidak hanya hukum-hukum yang berhubungan dengan agama yang partikular tetapi juga yang dasar, kebenaran-kebenaran spiritual yang tidak berubah, yang menurut Alquran telah disampaikan oleh setiap rasul Tuhan. Sementara hukum-hukum yang partikular (syir'ah dan minhaj) disebarluaskan melalui kebenaran tersebut dan jalan hidup (minhaj) dianjurkan olehnya, yang berubah-ubah sesuai dengan keadaan masa dan perkembangan kultural tiap-tiap komunitas masyarakat.

Meskipun ada "kesatuan dalam keragaman" dalam wahyu-wahyu Tuhan, jelas Asad, ${ }^{35}$ karena kegunaannya yang universal dan tidak diselewengkan secara tekstual (textual incorruptibility) dari ajaran-ajarannya --sebagaimana kenyataan Muhammad adalah penutup nabi-nabi (alAhzab/33:40)--Alquran menggambarkan poin yang final yang menyempurnakan jalan menuju pemenuhan spiritual. $^{36}$ Namun demikian, keunikan pesan Alquran ini tidaklah menghalangi para pengikut nabi-nabi yang awal untuk sampai pada kemurahan Tuhan: untuk mereka yang secara sungguh percaya pada Tuhan dan hari kemudian (yakni tanggung jawab moral individu) serta hidup secara adil tidak perlu takut dan bersedih hati (al-Baqarah/2:62 dan al-Maidah/5:69).

Prinsip pluralisme keagamaan inilah yang mendasari bahwa Allah menegur Nabi Muhammad ketika ia menunjukkan keinginannya agar orang-orang Yahudi dan orang-orang Nasrani mengikuti agama yang dibawanya sebagaimana dijelaskan pada sabab an-nuzul Ali Imran/3:64 di atas.

Delhi's 'Hujjat Allah Al-Baligha': Tension between the Universal and the Particular in an EighteenthCentury Islamic Theory of Religious Revelation," Studia Islamica, no. 63 (1986): 43-157, https://doi.org/10.2307/1595570. 
Teguran serupa dapat kita baca pada Yunus/10:99. Menurut Yusuf Ali, ${ }^{37}$ jika Allah menghendaki maka dengan kemahakuasaanNya Dia akan mencabut kebebasan yang telah diberikan kepada manusia dan membuatnya sama: semua beriman. Tetapi iman yang demikian tidak akan memantulkan pahala apaapa kepada mereka. Dalam kenyataan dunia ini, manusia telah dianugerahi bermacam-macam kemampuan dan kebebasan sehingga dengan demikian mereka akan berjuang dan berusaha keras dan menempatkan dirinya sesuai dengan kehendak Ilahi. Pada konteks ini, iman akan menjadi suatu prestasi moral. Orang beriman tidak boleh marah jika berhadapan dengan orang yang tidak beriman (atau tidak seagama dengannya) dan harus bisa menahan diri untuk melakukan kekerasan memaksakan iman kepada orang lain. Hal ini dikarenakan bahwa iman yang dipaksakan bukanlah iman. Manusia berusaha dengan jalan rohani dan biarlah Tuhan yang menentukan sesuai dengan kehendaknya.

\section{Sikap Positif terhadap Agama-agama}

Pada gilirannya, pandangan Alquran yang menghargai pluralitas keagamaan sebagai sesuatu yang natural dan cara keberagamaan yang inklusif ini melahirkan sikap yang positif ketika berhadapan dengan agama-agama lain. Berikut ini beberapa respon Alquran dan Nabi Muhammad menghadapi oposisi People of the Book (Yahudi dan Nasrani ketika itu) yang menggambarkan sikap positif Alquran tersebut.

\section{a. "Sapaan Mesra"}

Masih dalam konteks oposisi ahl al-kitab terhadap agama yang dibawa Nabi Muhammad, respon Alquran dikemukakan dengan bahasa yang halus dan, meminjam ungkapan Quraisy Shihab, ${ }^{38}$ tidak jarang dimulai dengan bahasa yang mengandung kesan 'kemesraan'. Respon-respon tersebut terasa lebih merupakan 'sapaan mesra' daripada kecaman pedas. Misalnya, tentang klaim Yahudi dan Nasrani terhadap Ibrahim, Alquran Surah Ali Imran/3:65 berkata: "Hai ahl al-

37 Yusuf Ali, The Holy Qur'an: Translation and Commentary (Jeddah: Dar al-Qibla, 1413 H), 510. kitab, mengapa kalian saling bantah tentang Ibrahim padahal Taurat dan Injil tidak diturunkan melainkan sesudah Ibrahim; apakah kalian tidak berpikir?"

Tentang sikap mereka yang mengingkari kebenaran Muhammad dan menyembunyikan sifat-sifat dan kedatangan beliau yang tertulis dalam kitab suci mereka, Alquran Surah Ali Imran/3:70,71, 98 dan 99 berkata:

Hai ahl al-kitab, mengapa kalian mengingkari ayat-ayat Allah padahal kamu mengetahui kebenarannya; Hai ahl al-kitab, mengapa kalian mencampuradukkan yang hak dan yang batil dan menyembunyikan kebenaran padahal kamu mengetahui?;

Katakanlah: "Hai ahl al-kitab, mengapa kalian ingkari ayat-ayat Allah padahal Allah Maha Menyaksikan apa yang kamu kerjakan?"

Katakanlah: "Hai ahl al-kitab, mengapa kalian menghalang-halangi dari jalan Allah orang-orang yang telah beriman, kalian menghendakinya menjadi bengkok padahal kalian menyaksikan? Allah sekali-kali tidak lalai dari apa yang kamu kerjakan.

Begitu pula sapaan itu terasa pada alMaidah/5:59:

Katakanlah: "Hai ahl al-kitab, apakah kalian menganggap kami salah hanya lantaran kami beriman kepada Allah, kepada kitab yang diturunkan kepada kami dan kepada kitab yang diturunkan sebelumnya. Sedang kebanyakan di antara kamu benar-benar orang-orang yang fasiq."

\section{b. Ahl al-Kitab Tidak Sama Semuanya}

Ketika Alquran mengungkapkan oposisi ahl al-kitab dan respon Alquran terhadap sikap mereka itu, pada kenyataannya hal itu tidak ditujukan kepada seluruh ahl al-kitab. Alquran tidak menggeneralisir ahl al-kitab dalam satu prototipe. Oleh karena itu, para mufassir bila menemukan istilah ahl al-

38 M. Quraisy Shihab, "Ahl Al-Kitab," in Rekontruksi Dan Renungan Religius Lslam, ed. M. Wahyuni Nafis (Jakarta: Paramadina, 1996), 5. 
kitab dalam sebuah ayat seringkali menjelaskan siapa yang dimaksud dengan istilah tersebut dengan cara merujuk pada sumber-sumber tradisional berupa hadis atau sejarah. ${ }^{39}$ Hal ini dapat kita lihat pada ayat-ayat yang sudah kita bahas di atas. Respon semacam ini dapat dipahami karena Alquran dengan tegas menyatakan bahwa tidak semua ahl al-kitab sama sikapnya terhadap Nabi, Alquran dan kaum Muslim. Di antara mereka terdapat orang-orang yang mempercayai kenabian Muhammad dan kebenaran Alquran sebagai wahyu Allah dan mendukung perjuangan Nabi atau ada juga yang masuk Islam (Ali Imran/3:113-114, 199).

Berkaitan dengan golongan yang dimaksud ayat di atas, menurut Ibn Abbas, ayat ini diwahyukan berkenaan dengan beberapa orang Yahudi yang masuk Islam dan membenarkan kerasulan Muhammad dan kewahyuan Alquran. Di antara mereka adalah Abdullah bin Salam, Sa'labah bin Syu'bah dan Asid bin Ubaid. $^{40}$

Ayat-ayat ini, menurut sumber-sumber tradisional, diwahyukan sehubungan dengan orang-orang Nasrani yang mempercayai kerasulan Muhammad dan mendukung perjuangan beliau. Ibn Jarir meriwayatkan, ketika Najasyi (raja Abbisinia yang beragama Nasrani) meninggal, Nabi Muhammad berkata: "Keluarlah kalian dan salatlah untuk saudara kalian". Kemudian Nabi keluar dan salat bersama para sahabat. Beliau bertakbir empat kali. Orang-orang munafik melihat hal itu dan berkata: "Lihatlah ini, Muhammad mensalati seorang Nasrani yang belum dilihatnya sama sekali." Kemudian turunlah Ali Imran/3:199. Riwayat lain mengatakan ayat tersebut diwahyukan ketika pengikut agama Nabi Isa mempercayai kenabian Muhammad. Mereka adalah 40 orang Nasrani Najran dari suku al-

\footnotetext{
${ }^{39}$ Pada kenyataannya, khususnya pada konteks ayatayat ahl al-kitab, tidak semua ayat memiliki keterangan sebab-sebab pewahyuannya (asbab al-nuzul). Selain itu, informasi-informasi yang disediakan asbab al-nuzul nyaris menggeneralisir dengan menyebutnya Yahudi atau Nasrani. Mungkin untuk memperoleh hasil kajian yang qualified diperlukan analisa sosiologis-historis yang mendalam.
}

Haris bin Kaab, 32 orang penduduk Habsyi (Abbisinia) dan 8 orang penduduk Romawi. ${ }^{41}$

Pada konteks ini, ternyata Alquran lebih memuji kepada penganut Nasrani daripada pengikut Yahudi. Sebaliknya, responrespon Alquran lebih banyak ditujukan kepada penganut Yahudi. Hal ini bisa dijelaskan bahwa sikap orang-orang Nasrani terhadap Nabi dan kaum Muslim relatif lebih bersahabat ketimbang sikap orang-orang Yahudi. Ini antara lain terlihat dalam sambutan dan perlindungan Raja Najasyi kepada sekelompok kaum Muslim ketika, karena alasan keselamatan, berhijrah ke Abbisinia (615 AD). Juga para pendeta Nasrani ketika itu bisa dikatakan relatif berhasil menanamkan ajaran moral yang bersumber dari ajaran Isa. Juga para rahib yang mencerminkan sikap zuhd berhasil pula memberi teladan kepada lingkungan pengikutnya. Hal ini didukung pula oleh tidak adanya kekuatan ekonomi-politik kaum Nasrani sehingga tidak mengundang gesekan dan benturan antara mereka dengan kaum Muslim. Sebaliknya, orang-orang Yahudi yang bersikap menetang Nabi dan kaum Muslim disebabkan kedengkian mereka akan kehadiran nabi terakhir bukan dari anak-keturunan mereka (alBaqarah/2:109) atau keberagamaan mereka yang eksklusif yang pada gilirannya mengakibatkan tergesernya pengaruh dan kepentingan ekonomi-politik mereka di kalangan masyarakat Madinah. Alquran dengan jelas menerangkan perbedaan sikap kedua penganut agama ini dalam alMaidah/5:82.

Selanjutnya, kepada orang-orang Yahudi dan Nasrani yang mengakui kenabian Muhammad dan mempercayai kitab yang diturunkan kepadanya, Alquran

${ }^{40}$ Syihab al-Din al-Sayyid Mahmud al-Bagdady Al-Alusy, Ruh Al-Ma'any Fi Al-Tafsir Alquran AlAzim Wa Al-Sab' Al-Masany (Beirut: Dar al-Kutub al-Ilmiyah, 1994), 248.

${ }^{41}$ Syihab al-Din al-Sayyid Mahmud al-Bagdady Al-Alusy, 80. 
memberikan pujian dan janji penghapusan kesalahan-kesalahan yang selama ini mereka perbuat. Dalam Ali Imran/3:110 kita membaca: "Seandainya ahl al-kitab beriman, tentu itu lebih baik; di antara mereka ada yang beriman dan kebanyakan mereka berbuat fasiq". Juga dalam al-Maidah/5:65: "Dan sekiranya ahl alkitab beriman dan bertakwa, tentulah kami hapus kesalahan-kesalahan mereka dan tentulah kami masukkan mereka ke dalam surga yang penuh kenikmatan." Dengan sikap seperti ini, berarti mereka mengakui kesinambungan wahyu Tuhan dan menyambungkan kembali 'rantai kenabian' yang telah mereka putuskan sebelumnya (dengan sikap keengganan mengakui kenabian Muhammad Saw. dan kewahyuan Alquran). "Dan sekiranya mereka sungguh-sungguh menjalankan Taurat, Injil dan (Alquran), yang diturunkan kepada mereka dari Tuhan mereka niscaya mereka akan mendapat makanan dari atas mereka dan dari bawah kaki mereka" (alMaidah/5:66).

\section{c. Larangan Ekstrimisme dalam Keberagamaan}

Jika sebelumnya orang-orang Yahudi yang banyak menjadi sasaran respon Alquran, kini orang-orang Nasrani pun tidak terlepas dari singgungannya. Respon Alquran terhadap mereka berhubungan dengan tumbuhnya penyimpangan dalam keagamaan mereka yang dalam bahasa Alquran disebut "melampaui batas dalam beragama". Pandangan Nasrani tentang Isa, nabi mereka, adalah masalah yang paling sering disinggung dan dikritik oleh Alquran. Dalam pandangan Alquran, pendapatpendapat mereka tentang Isa jelas sekali merupakan tindakan melampaui batas-batas agama (al-ghuluw fi al-din) (al-Nisa/4:171; alMaidah/5:77).

Kedua ayat tersebut bisa dikatakan semacam teguran dan peringatan Allah terhadap kaum Nasrani yang telah melewati batas-batas dalam beragama: menempatkan Isa tidak pada posisi yang telah diberikan Allah kepadanya sebagai hamba dan rasul-Nya dan menjadikannya

${ }^{42}$ Al-Dimasqy, Mukhtasar Tafsir Ibn Kasir, 458.

Al-Dimasqy, Mukhtasar Tafsir Ibn Kasir, vol. 1, 458. sebagai Tuhan selain Allah. Pandangan kaum Nasrani ini pada perjalanan sejarahnya melahirkan doktrin Trinitas. Oleh karena itu, pada ayat tersebut pula Allah memerintahkan mereka menempatkan kembali Allah dan Isa pada proporsinya masing-masing sebagaimana adanya; Allah itu satu yang transenden dan suci dari memiliki anak dan Isa adalah hamba Allah yang diutus menjadi rasul-Nya seperti rasul-rasul lainnya. Hal ini telah menjadi visi masa depan Alquran tentang akan berimannya ahl al-kitab kepada Isa sebagaimana adanya (al-Nisa/4:159).

Menurut Ibn Jarir, ${ }^{42}$ tak seorang pun ahl al-kitab setelah turunnya Isa kecuali beriman kepadanya sebelum kematiannya sebagaimana mestinya. Mereka akan membatalkan klaim-klaim tentang Isa yang selama ini mereka yakini; klaim Yahudi bahwa mereka telah membunuh Isa dan menyalibnya dan klaim Nasrani Isa sebagai anak Tuhan. Ayat di atas nampaknya mempunyai kaitan dengan doktrin Messianik; kembalinya Isa ke bumi menjelang hari kiamat yang benyak bersumber pada hadis. ${ }^{43}$

Setelah menegur orang-orang YahudiNasrani karena melampaui batas-batas agama, Alquran menyuruh mereka kembali kepada garis-garis yang telah ditetapkan kitab suci tersebut sebagai pemutus segala persoalan dan mengakui kebenaran kitabkitab suci lainnya. Tanpa ini semua, keberagamaan mereka tidak berarti apa-apa (al-Maidah/5:47; al-Maidah/5:68).

\section{d. Beberapa Tindakan Politis terhadap Koloni Yahudi}

Yang terakhir, ini bisa dikatakan merupakan respon Alquran paling keras terhadap oposisi ahl al-kitab. Dalam hal ini, Alquran 'merekam' dua peristiwa yang keduanya berkenaan dengan orang-orang Yahudi. Pertama, pengusiran koloni Yahudi Banu Nadhir dari Madinah dan

43 Abu Abdillah Muhammad bin al-Bukhary Ismail, Shahih Al-Bukhary, vol. 2 (Beirut: Dar alFikr, t.th.), 256. 
kedua, penyelesaian secara militer terhadap koloni Yahudi Banu Quraizah.

Tentang yang pertama dapat dibaca dalam al-Hasyr/59:2. Para ahli tafsir ketika menafsirkan ayat ini selalu menghubungkannya dengan pembatalan sebelah pihak yang dilakukan oleh koloni Banu Nadhir terhadap pakta perdamaian yang disepakati antara mereka dengan Nabi Muhammad. Ketika Nabi memasuki Madinah, Banu Nadhir, salah satu koloni Yahudi besar di Madinah, menawarkan perjanjian damai kepadanya bahwa mereka tidak akan mengadakan kontak senjata terhadap Nabi dan kaum Muslim. Nabi menerima perjanjian damai tersebut. Namun, ketika kaum Muslim mengalami kekalahan dalam perang Uhud, mereka membatalkan perjanjian dan memperlihatkan permusuhan terhadap Nabi dan kaum Muslim. Nabi melihat ini sebagai pengkhianatan terhadap pakta yang telah disepakati. Kemudian, Nabi dan kaum Muslim mengepung koloni Banu Nadhir dan mengusir mereka dari Madina, yang terjadi pada tahun keempat Hijrah. ${ }^{44}$

Ketika terjadi pengusiran Banu Nadhir, sekelompok orang-orang munafik pimpinan Abdullah bin Ubay memperlihatkan rasa simpati kepada mereka. Mereka mengatakan akan sama-sama pergi ketika Banu Nadhir diusir dari Madinah dan akan membantu mereka kalau mereka diserbu. Tapi, ternyata janji mereka tersebut hanya omong kosong. Mereka melakukan itu hanya untuk menunjukkan sikap penentangan terhadap Nabi (Al-Hasyr/59:11).

Sementara itu, tentang yang kedua, yaitu penyelesaian secara militer terhadap koloni Yahudi Banu Quraizah, Alquran menjelaskannya dalam al-Ahzab/33:26. Seperti koloni Yahudi lainnya di Madinah, Banu Quraizah terikat perjanjian damai yang disepakati antara mereka dan kaum Muslim. Namun, ketika perang Ahzab (5 AH/ 627 AD),

44 Keterangan lebih lengkap tentang pengusiran koloni Yahudi Banu Nadir, lihat Al-Wahidy, Asbab AlNuzul, 236. Lihat juga Al-Dimasqy, Mukhtasar Tafsir Ibn Kasir, 469-470. Lihat juga Khan, Muhammad the Final Messenger, 197-202. dengan bujukan Huyayy bin Akhtab, pimpinan Banu Nadhir, mereka beraliansi dengan faksi-faksi yang terdiri dari suku Quraisy dan suku Arab lainnya yang hendak menyerang dan mengepung Madinah. Situasi pada saat itu bisa dikatakan kaum Muslim menghadapi ancaman dari tiga pihak sekaligus: aliansi suku-suku Arab (kaum musyrikin), orang-orang munafik dan koloni Yahudi yang bergabung dengan aliansi. Jelas, secara politik hal ini tidak menguntungkan dan merupakan pengkhianatan terhadap pakta perdamaian yang disepakati. Setelah perang Ahzab dimenangkan kaum Muslim dan aliansi bercerai-berai, sebagai konsekuensi pembatalan pakta perdamain secara sepihak, Nabi dan kaum Muslim mengepung perkampungan koloni Banu Quraizah. Nabi menawarkan negosiasi yang kemudian mereka tolak. Sebagai akibatnya, Nabi mengerahkan kekuatan militer, memerangi mereka dan memaksa mereka keluar dari benteng-benteng perlindungan. Pertumpahan darah tidak bisa dihindari. Sejumlah orang Yahudi terbunuh dan yang lainnya ditawan. ${ }^{45}$

Dari uraian di atas, tampak bahwa Alquran dan Nabi Muhammad tidak mempersoalkan agama Yahudi dan Nasrani sebagai wahyu yang valid. Yang dipersoalkan adalah sikap-sikap kaum Yahudi dan kaum Nasrani yang secara arogan mengingkari Alquran sebagai bagian dari rangkaian wahyu Allah dan Muhammad sebagai bagian dari rantai silsilah kenabian karena berbagai kepentingan ekonomi-politik mereka. Respon-respon Alquran dan tindakan Nabi tersebut tidak didasarkan pada ketidakabsahan agama Yahudi dan Nasrani, melainkan lebih pada alasan-alasan lain. Pada kasus dua koloni Yahudi di atas, tindakan Nabi --karena betul-betul

\footnotetext{
45 Penjelasan lebih lengkap peristiwa pengepungan koloni Banu Quraizah, lihat AlDimasqy, Mukhtasar Tafsir Ibn Kasir, 90-91; Khan, Muhammad the Final Messenger, 222-230; AlIsmail, The Life of Muhammad: His Life Based on the Earliest Source, 149-151.
} 
memahami pesan Alquran tentang ahl al-kitab- tidak didasarkan pada motivasi valid-tidaknya agama Yahudi yang mereka anut, melainkan lebih pada persoalan integritas umat yang sedang dibangun oleh Nabi. Jadi, alasannya lebih bersifat politis daripada keagamaan. Hal ini dengan jelas memperlihatkan pandangan Islam yang melihat ahl al-kitab sebagai penganut agama yang otentik dan mengakui pluralitas keagamaan sebagai hal yang natural dan valid.

\section{SIMPULAN}

Dengan menganalisis ayat-ayat yang berbicara tentang People of the Book (Ahl alKitab), yakni penganut Yahudi dan Nasrani pada zaman Nabi Muhammad, sikap mereka kepada Nabi Muhammad, Islam yang dibawanya dan kaum Muslim, dan bagaimana respon Alquran atas mereka, bisa dipahami bahwa dalam perspektif Alquran, pluralisme keagamaan merupakan persoalan yang absah. Pluralitas masyarakat adalah prinsip dasar Alquran. Pluralitas masyarakat ini meniscayakan pluralitas sistem keagamaan atau kepercayaan di mana tiap komunitas menjadikannya sebagai jalan hidup. Keterangan Alquran tentang adanya rasul dan jalan hidup bagi setiap komunitas merupakan bukti bahwa pluralitas (keragaman) agama adalah absah sebagai bagian dari kehendak Allah.

Pluralisme keagamaan yang diakui Alquran bukanlah dalam pengertian keberbedaan yang total. Agama-kitab beragam, yang berarti pula berbeda, pada dimensi bentuk atau syir'ah dan minhaj dalam bahasa Alquran. Tetapi, pada saat yang sama dalam keragaman tersebut terdapat kesamaan substansial pada dimensidalamnya atau din dalam istilah Alquran. Dalam pandangan Alquran, kesatuan transenden itu terletak pada ajaran monoteisme (tawhid dalam istilah ilmu kalam) yang secara universal menjadi pesan inti agama-kitab. Kesamaan inilah yang menjadi semacam titiktemu (common term) dalam semua agamakitab. Kepada monoteisme inilah Alquran mengajak agama-kitab lainnya untuk mencari titik-temu. Pada kesatuan transenden inilah sebenarnya terletak pertemuan sejati agama- agama. Yang mungkin menjadi perbedaan adalah pada tataran kesejarahan artikulasi monoteisme tersebut relatif berbeda pada tiap agama-kitab.

Cara keberagamaan yang inklusif ini mendasari sikap dan respon Alquran terhadap agama-agama lain: tidak menafikan validitasnya dan lebih menekankan pada titik kesamaan seperti yang diperlihatkan dalam merespon oposisi People of the Book (Ahl al-Kitab; komunitas Yahudi dan Nasrani di Madinah). Yang diharapkan, lebih tegasnya dituntut, oleh Alquran dari adanya pluralisme keagamaan adalah hendaknya setiap komunitas pemeluk agama mengamalkan jaran-ajaran Kitab Sucinya dengan sepenuhnya dalam upaya mendekati Realitas Absolut dan saling berlomba memberikan yang terbaik dengan cara yang dapat dibenarkan bagi kemaslahatan dan kepenetingan seluruh komunitas.

\section{DAFTAR PUSTAKA}

Al-Bagawy, Abu Muhammad al-Husein bin Mas'ud al-Farra'. Ma'alim Al-Tanzil Fi Al-Tafsir-Wa Al-Tawil. Beirut: Dar alFikr, 1985.

Al-Dimasqy, Imaduddin Abi al-Fida Ismail bin Kasir. Mukhtasar Tafsir Ibn Kasir. Edited by Muhammad Al-Sabuny. Kairo: Dar al-Turas al-Araby, 1987.

Al-Ismail, Tahia. The Life of Muhammad: His Life Based on the Earliest Source. London: Ta-Ha Publisher, 1993.

Al-Maragy, Ahmad Mustafa. Tafsir AlMaragy. Beirut: Dar al-Fikr, 1974.

Al-Qattan, Manna Khalil. Mabahis Fi Ulum Al-Quran Edisi Indonesia, Studi IlmuIlmu Quran. Translated by Muzakir. Jakarta: Pustaka Litera Antar Nusa, 2000.

Al-Wahidy, Abu al-Hasan Aly bin Ahmad. Asbab Al-Nuzul. Beirut: al-Maktabah alTsaqafiyyah, 1989.

Albayrak, Ishmael. "The People of the Book in the Qur'an." Islamic Studies 47, no. 3 (2008): 301-325.

Ali, Yusuf. The Holy Qur'an: Translation and Commentary. Jeddah: Dar al-Qibla, 
1413.

Asad, Muhammad. The Message of the Qur'an. Gibraltar: Dar al-Andalus, 1980.

Assagaf, Ja'far. "Hubungan Muslim Dengan Non Muslim Dalam Perspektif Hadis." UIN Jakarta, 2008.

Boulatta, Issa J. "Modern Qur'an Exegesis: A Study of Bint Ash-Shathi's Method." The Muslim World 64, no. 2 (1974): 104-5.

Esposito, John L. Ahl Al-Kitab. The Oxford Dictionary of Islam. Oxford: Oxford University Press, 2014.

Farah, Naila. "Konsep Ahl Al-Kitab Menurut Pemikiran Rasyid Ridha Dalam Tafsir AlManar." Rausyan Fikr 12, no. 2 (2016): 221-49.

Glasse, Cyril. The Concise Encyclopedia of Islam. London: Stacey International, 1989.

Halbertal, Moshe. People of the Book: Canon, Meaning, and Authority. Cambridge: Harvard University Press, 1997.

Hermansen, Marcia K. "Shah Wali Allah of Delhi's 'Hujjat Allah Al-Baligha': Tension between the Universal and the Particular in an Eighteenth-Century Islamic Theory of Religious Revelation." Studia Islamica, no. 63 (1986): 43-157. https://doi.org/10.2307/1595570.

Huntington, Samuel Phillips. "Benturan Kebudayaan, Masa Depan Politik Dunia?" Ulumul Qur'an 4, no. 5 (1993).

Ishaq, Ibn. Al-Sirah Al-Nabawiyyah. Kairo: Darul Kutub al-Misriyah, t.th.

Ismail, Abu Abdillah Muhammad bin alBukhary. Shahih Al-Bukhary. Vol. 2. Beirut: Dar al-Fikr, t.th.

Jauhari, Syeikh Tantawi. Al-Jawahir Fi Tafsir Al-Qur'an Al-Karim. Beirut: Dar al-Fikr, 1900.

Khan, Madjid Ali. Muhammad the Final Messenger. Delhi: Idarah-i Adabiyat-i Delhi, 1980.

Madjid, Nurcholish. "Islamic Roots of Modern Pluralism: Indonesian Experience." Studia Islamika 1, no. 1 (2014): 55-77. https://doi.org/10.15408/sdi.v1i1.866.

-. "Pluralisrne Agama Di Indonesia." Ulumul Qur'an 6, no. 3 (1995): 63.

Muhammad al-Razy Fakhruddin ibn alAllamah Diya ad-Din Umar. Mafatih Al-
Gayb. Beirut: Dar al-Fikr, 1981.

Naisbitt, John, and Patricia Aburdene. Magatrends 2000. Jakarta: Binarupa Aksara, 1990.

Nasution, Syamsudin. "Makna Ahl AlKitab Dalam Al-Qur'an (Suatu Kajian Tematik)." Toleransi 1, no. 2 (2019): 184-206.

Noorhidayati, Salamah. "Relasi Antar Umat Beragama Dalam Perpektif Hadits." Kalam 10, no. 2 (2017): 491-516.

Rahman, Fazlur. Tema Pokok Alquran. Bandung: Mizan, 2017.

Ridla, Muhammad Rasyid. Tafsir AlManar. Vol. 6. Beirut: Dar al-Ma'rifah, t.th.

Sabjan, Muhammad Azizan, and Noor Shakirah Mat Akhir. "The Concept of the People of the Book (Ahl Al-Kitab) in Islamic Religious Tradition." AFKAR: Jurnal Akidah \& Pemikiran Islam 6, no. 1 (2005): 15-36.

Shihab, M. Quraisy. "Ahl Al-Kitab." In Rekontruksi Dan Renungan Religius Lslam, edited by M. Wahyuni Nafis. Jakarta: Paramadina, 1996.

Sumbulah, Umi. "Islam Dan Ahl Al-Kitāb : Kajian Living Sunnah Di Kalangan Pimpinan NU, Muhammadiyah Dan Hizbut Tahrir Malang." Al-Tahrir: Jurnal Pemikiran Islam 11, no. 1 (2011): 151-71.

Syakir, Syaikh Ahmad. Mukhtashar Tafsir Ibnu Katsir. Jakarta: Darus Sunnah Press, 2014.

Syihab al-Din al-Sayyid Mahmud alBagdady Al-Alusy. Ruh Al-Ma'any Fi Al-Tafsir Alquran Al-Azim Wa Al-Sab' Al-Masany. Beirut: Dar al-Kutub alIlmiyah, 1994.

Wahyudi, Jarot. "Exegetical Analysis of The Ahl Al-Kitab Verses of the Qur'an." Islamic Studies 37, no. 4 (1998): 425-43.

Watt, Montgomery, and Richard Bell. Pengantar Studi Alquran. Translated by Taufik Adnan Amal. Jakarta: PT Raja Grafindo Persada, 1995.

Watt, W. Montgomery. Muhammad's Mecca. Edinburgh: Edinburgh University Press, 1988. 
Yahya, Yunus. Muslim Tionghoa. Jakarta: Yayasan Ukhuwah Islamiyah, 1985.

Zulyadain. "Menimbang Kontorversi Pemaknaan Konsep Ahl Al-Kitāb Dalam Al-
Qur'an." Ulumuna Jurnal Studi Keislaman 16, no. 2 (2012): 279-310. https://doi.org/10.20414/ujis.v16i2.180. 